\title{
Triiodothyronine modulates the expression of leptin and adiponectin in 3T3-L1 adipocytes
}

\author{
Triiodotironina modula a expressão de leptina e adiponectina em adipócitos 3T3-L1
}

\author{
Miriane de Oliveira ${ }^{1}$, Maria Teresa De Síbio ${ }^{1}$, Regiane Marques Castro Olimpio ${ }^{1}$, Fernanda Cristina Fontes Moretto ${ }^{1}$, \\ Renata de Azevedo Melo Luvizotto ${ }^{2}$, Celia Regina Nogueira ${ }^{1}$
}

\begin{abstract}
Objective: To study the effect of different doses of triiodothyronine on gene expression of the adipokines leptin and adiponectin, at different times, and to evaluate the difference in expression between the two adipokines in each group. Methods: 3T3-L1 adipocytes were incubated with triiodothyronine at physiological dose $(10 \mathrm{nM})$ and supraphysiological doses $(100 \mathrm{nM}$ or $1,000 \mathrm{nM})$, or without triiodothyronine (control, C) for $0.5,6$, or 24 hours. Leptin and adiponectin mRNA was detected using real-time polymerase chain reaction (RT-PCR). One-way analyses of variance, Tukey's test or Student's $t$ test, were used to analyze data, and significance level was set at $5 \%$. Results: Leptin levels decreased in the 1,000nM-dose group after 0.5 hour. Adiponectin levels dropped in the $10 \mathrm{nM}$-dose group, but increased at the $100 \mathrm{nM}$ dose. After 6 hours, both genes were suppressed in all hormone concentrations. After 24 hours, leptin levels increased at 10, 100 and 1,000nM groups as compared to the control group; and adiponectin levels increased only in the 100nM group as compared to the control group. Conclusion: These results demonstrated fast actions of triiodothyronine on the leptin and adiponectin expression, starting at 0.5 hour, at a dose of $1,000 \mathrm{nM}$ for leptin and $100 \mathrm{nM}$ for adiponectin. Triiodothyronine stimulated or inhibited the expression of adipokines in adipocytes at different times and doses which may be useful to assist in the treatment of obesity, assuming that leptin is increased and adiponectin is decreased, in obesity cases.
\end{abstract}

Keywords: Leptin; Adiponectin; Triiodothyronine; Adipocytes

\section{RESUMO}

Objetivo: Examinar o efeito de diferentes doses de triiodotironina sobre a expressão gênica das adipocinas leptina e adiponectina, em diferentes períodos de tempo, além de avaliar a diferença de expressão entre as duas adipocinas em cada grupo. Métodos: Adipócitos 3T3-L1 foram incubados com triiodotironina nas doses fisiológica (10nM) e suprafisiológicas (100nM ou $1.000 \mathrm{nM})$, ou na ausência de triiodotironina (controle, C) durante $0,5,6$ ou 24 horas. 0 mRNA das adipocinas foi analisado em tempo real, utilizando a reação em cadeia de polimerase. Para as análises dos dados, foi utilizada a análise de variância, complementada com o teste de Tukey, ou 0 teste $t$ de Student com $5 \%$ de significância. Resultados: 0 s níveis de leptina diminuíram no grupo com dose de $1.000 \mathrm{nM}$ em 0,5 hora. A adiponectina também diminuiu no grupo com dose de $10 \mathrm{nM}$, porém se elevou com a dose de 100nM. Após 6 horas, ambos os genes foram suprimidos em todas concentrações de hormônio. Em 24 horas, os níveis de leptina foram elevados em 10, 100 e 1.000nM, em relação ao grupo controle. No que concerne à adiponectina, observou-se aumento apenas no grupo cuja dose foi de $100 \mathrm{nM}$, em comparação ao controle. Conclusão: Foram demonstradas ações rápidas da triiodotironina sobre a expressão da leptina e da adiponectina, iniciando em 0,5 hora na dose de $1.000 \mathrm{nM}$, para a primeira, e na dose de $100 \mathrm{nM}$, para a segunda. A triiodotironina estimulou ou inibiu a expressão de adipocinas em adipócitos em diferentes tempos e doses, o que pode auxiliar no tratamento da obesidade, levando em consideração que, nesta, a leptina está aumentada e adiponectina, diminuída.

Descritores: Leptina; Adiponectina; Tri-lodotironina; Adipócitos

\section{INTRODUCTION}

The effects of thyroid hormones (THs) are especially important during development, since they regulate the growth and maturation of different organs and tissues during fetal and neonatal life..$^{(1,2)}$ Many tissues are

\footnotetext{
1 Universidade Estadual Paulista "Júlio de Mesquita Filho", Botucatu, SP, Brazil.

2 Universidade Federal de Mato Grosso, Cuiabá, MT, Brazil.

Corresponding author: Miriane de Oliveira - Distrito de Rubião Jr., s/n - Distrito Rubião Jr - Zip code: 18618-000 - Botucatu, SP, Brazil - Phone: (55 14) 3881 -6213 - E-mail: miriane.deoliveira@yahoo.com.br Received on: Feb 16, 2014 - Accepted on: Jan 12, 2015

Conflitos de interesse: não há.
}

DOI: 10.1590/\$1679-45082015A03068 
regulated by THs to their full development, including effects on gene groups involved in the differentiation process. Like other tissues, the adipose tissue (AT) is an important target for $\mathrm{THs},{ }^{(3)}$ because it specializes in transport, synthesis, storage and mobilization of lipids. Its primary function is the storage of energy in the form of triglycerides, providing a reserve of energy to be used in times of caloric deprivation. ${ }^{(4)}$ The AT is the largest endocrine organ in the whole body, secreting hormones, chemokines and adipokines, which are important paracrine/ endocrine regulators. ${ }^{(5)}$

THs, especially triiodothyronine (T3), modulate the proliferation and differentiation of adipocytes ${ }^{(6)}$ and are involved in cellular processes such as signal transduction, apoptosis, and inflammatory response.

Leptin and adiponectin are adipokines synthesized and secreted by the AT. Leptin acts mainly on the central nervous system, producing anorectic effects and stimulating energy expenditure. ${ }^{(7)}$ Adiponectin is involved in important metabolic effects, such as stimulating fatty acid oxidation, reducing gluconeogenesis and increasing thermogenesis. ${ }^{(8-11)}$

Obese humans have high serum levels of leptin. Leptin concentrations are directly proportional to body fat mass, specifically the volume of adipocytes. ${ }^{(12,13)}$ Regarding THs, there is evidence indicating that human obesity is usually associated with increased levels of thyroid stimulating hormone (TSH) and T3. ${ }^{(14,15)}$ As in mice, human studies came to conflicting results on the effect of THs on leptin concentrations. In subjects with hypothyroidism, leptin was found increased, ${ }^{(16,17)}$ decreased $^{(18,19)}$ or unchanged ${ }^{(20,21)}$ when compared with euthyroid individuals. The same controversial results are found in studies with hyperthyroidism patients. ${ }^{(16-22)}$

The administration of $\mathrm{T} 3$ in hypothyroid rats decreased the messenger RNA (mRNA) expression of leptin in the AT and circulating levels of leptin. ${ }^{(23)}$ However, in other studies, THs increased leptin in adipocytes differentiated from 3T3-L1 cells. ${ }^{(24)}$ Studies in humans did not show conclusive evidence on the relationship between THs and leptin levels. ${ }^{(25,26)}$

Adiponectin shares some physiological effects with THs, such as reducing body fat, increasing thermogenesis and promoting lipid oxidation. ${ }^{(27)}$

The interaction between THs and adiponectin concentrations is still undefined. Some studies suggest that thyroid function has influence on its serum levels. Some authors have reported that the concentration of this adipokine is higher in hyperthyroidism, when compared with hypothyroidism in patients with Graves' disease $^{(28)}$ and in euthyroid patients with Basedow's disease. ${ }^{(29)}$
Studies on a possible relation between adiponectin and deviations in lipid metabolism associated with thyroid dysfunction are scarce. Patients with hyperthyroidism showed increased body weight, cholesterol and body mass index after controlling for thyrotoxicosis. After adjusting adiponectin levels for body mass index, no significant change was observed in patients with hyperand hypothyroidism, suggesting that THs play a small role in the modulation of adiponectin levels. ${ }^{(30)}$

THs act by increasing the metabolic rate and oxygen consumption, regulating heat production and energy supply; leptin and adiponectin are involved in the regulation of energy balance. ${ }^{(31)}$

Conflicting results may be explained by the existence of many factors influencing the levels of leptin, adiponectin and THs, and more studies are needed to fully explain the relation between leptin, adiponectin and THs.

The biological roles of THs, leptin and adiponectin intersect at regulation of energy expenditure, and this provides a way to study the response of the AT to T3 without the interference of systemic factors. Therefore, we evaluated the effects of different doses of T3 at different timepoints on the levels of gene expression of leptin and adiponectin, in vitro, in 3T3-L1 cells differentiated into adipocytes. Both adipokines are modulated by $\mathrm{T} 3$ over short or long periods, increasing or decreasing, according to the dose of this hormone.

Our study aims to demonstrate that physiological doses of $\mathrm{T} 3$ act by decreasing gene expression of adiponectin and increasing that of leptin. However, supraphysiological doses of T3 act over longer time frames, increasing the concentration of leptin and decreasing that of adiponectin. Our results confirm the action of T3 on the AT at the physiological dose and allow for further studies on the use of T3 in the treatment of obese patients. As shown in the literature, after losing $5-10 \%$ of weight, weight loss becomes more difficult, ${ }^{(32)}$ and patients show low serum T3 levels. ${ }^{(33)}$ Therefore, our findings could warrant the administration of physiological doses of the hormone at this stage of the treatment.

\section{OBJECTIVE}

To study the effect of different doses of triiodothyronine on gene expression of the adipokines leptin and adiponectin over different time periods, and assess the difference in expression between the two adipokines in each group. 


\section{METHODS}

\section{Cell culture and differentiation}

The experimental protocol was approved by the Ethics Committee for Animal Studies of the Faculdade de Medicina de Botucatu da Universidade Estadual Paulista "Júlio de Mesquita Filho", under number 752.

For the in vitro study, we used the cell line 3T3-L1. These cells were obtained from the Cell Bank of the Universidade Federal do Rio de Janeiro (UFRJ) and cultured as described in the literature, ${ }^{(34)}$ in Dulbecco's modified medium (DMEM; Gibco ${ }^{\circledR}$ ) supplemented with $10 \%$ fetal bovine serum (FBS; Gibco $\left.^{\circledR}\right), 1 \%$ antibiotic/antimycotic $\left(\right.$ Sigma $\left.^{\circledR}\right)$, under an atmosphere of $5 \%$ carbon dioxide $\left(\mathrm{CO}_{2}\right)$ at $37^{\circ} \mathrm{C}$. The cells were kept under culture in said conditions until reaching a confluence of approximately $100 \%$, and then were transferred to six-well plates for the experiments. After reaching $100 \%$ confluence in the wells, the cells were subjected to differentiation. They were kept for 3 days in DMEM containing 10\% FBS, 100mM 1-methyl-3isobutylxanthine (IBMX; Sigma ${ }^{\circledR}$ ), 1mM dexamethasone $\left(\right.$ Sigma $\left.^{\circledR}\right)$ and $5 \mathrm{mg} / \mathrm{L}$ insulin $\left(\right.$ Sigma $\left.^{\circledR}\right)$. After this period, the cells were left for 7 days in DMEM containing $10 \%$ FBS and $5 \mathrm{mg} / \mathrm{mL}$ insulin. After cell differentiation, adipocytes were subjected to TH depletion for 36 hours in DMEM supplemented with Charcoal-Stripped Fetal Bovine Serum $\left(\right.$ Sigma $\left.^{\circledR}\right)$. After TH depletion, the cells were treated with T3 at the physiological dose $(10 \mathrm{nM}$, designated F) or supraphysiological doses (100nM and 1,000nM, designated SI and SII, respectively) for 0.5, 6 and 24 hours. The group not treated with $\mathrm{T} 3$ was used as control (C).

\section{Oil Red 0 Staining}

After 10 days of differentiation, the culture medium was removed from the cells and they were washed twice with phosphate-buffered saline (PBS). Thereafter, we added $1 \mathrm{~mL}$ formaldehyde, in which the cells were left for 30 minutes at room temperature. After this time, the cells were washed three times with PBS. Then we added $300 \mu \mathrm{L}$ Oil Red $O\left(\right.$ Sigma $\left.^{\circledR}\right)$, and the cells were incubated for 2 hours at $37^{\circ} \mathrm{C}$. After this period, they were again washed three times with distilled water and placed in oven to dry. The cells were observed under a microscope for verification of the differentiation by red staining of adipose cells.

\section{Gene expression}

Total RNA was extracted from 3T3-L1 cells using TRIzol ${ }^{\circledR}$ (Invitrogen ${ }^{\circledR}$ ) as reagent, according to the manufacturer's instructions. The High Capacity cDNA kit for reverse transcription in real-time polymerase chain reaction (RT-PCR, Invitrogen, São Paulo, Brazil) was used for the synthesis of $20 \mu \mathrm{L}$ complementary DNA (cDNA) from 1,000 ng total RNA.

The levels of adiponectin (Applied Biosystems assay Mm00456425_m1) and leptin (Applied Biosystems assay Mm00434759_m1) were analyzed by real-time PCR (RT-PCR). Analyzes were performed on Applied Biosystems StepOne Plus, a detection system that uses the Taqman qPCR commercial kit (Invitrogen) according to the manufacturer's instructions. The amplification conditions were as follows: enzyme activation at $50^{\circ} \mathrm{C}$ for 2 minutes; denaturation at $95^{\circ} \mathrm{C}$ for 10 minutes; cDNA products amplified with 40 denaturation cycles at $95^{\circ} \mathrm{C}$ for 15 seconds; and annealing/extension at $60^{\circ} \mathrm{C}$ for 1 minute.

After normalization to the internal control, cyclophilin (assay Mm00434759_m1), ${ }^{(34)}$ using the $2^{-\Delta \Delta \mathrm{Ct}}$ method as previously described, ${ }^{(35)}$ the mRNA expression of leptin or adiponectin was evaluated for comparison between the values of Group $\mathrm{C}$ and the treatment groups (F, SI, SII), or comparison of the difference between expression of leptin and adiponectin within the same group. Relative quantification of gene expression was performed with the comparative $\mathrm{Cq}$ method. ${ }^{(35)}$

\section{Statistical analysis}

The differences between mRNA levels of leptin and adiponectin in each group, whether or not treated, were analyzed by the Student $t$ test. The differences in expression of the gene for leptin or adiponectin, at different $\mathrm{T} 3$ doses in each timepoint were assessed by analysis of variance (ANOVA) followed by Tukey's test. Data were expressed as mean \pm standard deviation. The level of significance was set at $5 \%$.

\section{RESULTS}

\section{T3-L1 Cell culture and differentiation}

Figure 1A shows 3T3-L1 cells prior to differentiation. In the presence of the differentiation solution (insulin, dexamethasone and IBMX), preadipocytes developed the morphology of mature adipocytes (Figures $1 \mathrm{~B}$ and $1 \mathrm{C}$ ), with primary features, including a large number of cytoplasmic lipid droplets. Staining with Oil Red $O$ highlighted the lipid droplets in red (Figure 1C). 


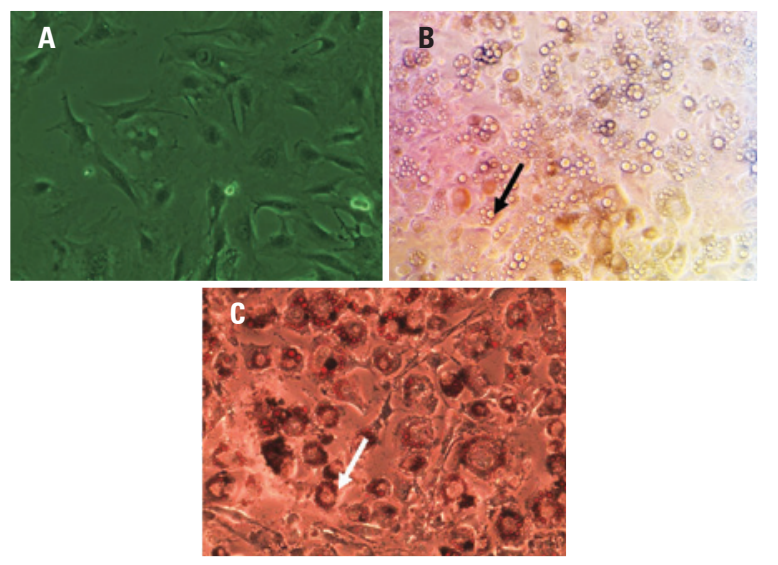

Figure 1. 3T3-L1 cells before and after differentiation into adipocytes. (A) Nondifferentiated cells. (B) Cells after 10 days of differentiation. (C) Cells stained with Oil Red 0 after 10 days of differentiation. The arrows show the adipocyte with cytoplasmic lipid droplets

\section{Level of expression of adipokines in 3T3-L1 adipocytes} Table 1 shows the difference in expression levels between adipokines leptin and adiponectin for all groups at different timepoints. Adiponectin, whether with or without treatment, showed higher expression levels than leptin.

Table 1. Adiponectin versus leptin at different timepoints within each group in the absence (control) or presence (10nM, 100nM and 1,000nM) of triiodothyronine

\begin{tabular}{ccccc}
\hline & $\begin{array}{c}\text { Groups according } \\
\text { to timepoints }\end{array}$ & $\begin{array}{c}\text { Adiponectin } \\
\text { M } \pm \text { SD }\end{array}$ & $\begin{array}{c}\text { Leptin } \\
\text { M } \pm \text { DP }\end{array}$ & p value \\
\hline $0.5 \mathrm{hr}$ & C & $1.00 \pm 0.18$ & $0.000034 \pm 0.000003$ & $<0.001$ \\
& F & $0.28 \pm 0.08$ & $0.000032 \pm 0.000005$ & 0.005 \\
& SI & $3.08 \pm 0.24$ & $0.000017 \pm 0.000003$ & $<0.001$ \\
\hline $6 \mathrm{hr}$ & SII & $1.35 \pm 0.10$ & $0.000007 \pm 0.000001$ & $<0.001$ \\
& C & $1.00 \pm 0.15$ & $0.000033 \pm 0.000008$ & $<0.001$ \\
& F & $0.23 \pm 0.05$ & $0.000016 \pm 0.000003$ & 0.002 \\
& SI & $0.27 \pm 0.03$ & $0.000018 \pm 0.000001$ & $<0.001$ \\
& SII & $0.28 \pm 0.05$ & $0.000004 \pm 0.0000008$ & $<0.001$ \\
& C & $1.00 \pm 0.17$ & $0.000029 \pm 0.000001$ & $<0.001$ \\
& F & $1.18 \pm 0.12$ & $0.000045 \pm 0.000007$ & $<0.001$ \\
& SI & $1.75 \pm 0.45$ & $0.000248 \pm 0.000042$ & 0.003 \\
& SII & $0.71 \pm 0.14$ & $0.000089 \pm 0.000001$ & $<0.001$ \\
\hline
\end{tabular}

The mRNAs for adiponectin and leptin were analyzed by real-time polymerase chain reaction. Data expressed as mean \pm standard deviation. Comparison of adiponectin versus leptin levels, within each group, with the Student $t$ test. All assays were performed in triplicate ( $\mathrm{n}=3$ for each treatment). M: mean; SD: standard deviation; $\mathrm{C}$ : control; F: triiodothyronine at 10nM; SI: triiodothyronine at 100nM; SII: triiodothyronine at 1,000nM.

Different doses of triiodothyronine suppress mRNA levels for leptin at 0.5 and 6 hours, but supraphysiological doses increase levels at 24 hours

Figure 2 shows the modulation of mRNA levels for leptin in 3T3-L1 adipocytes, in the absence $(\mathrm{C})$ or presence $(\mathrm{F}$, SI, SII, respectively) of T3 at different timepoints $(0.5,6$ and 24 hours) by RT-PCR.
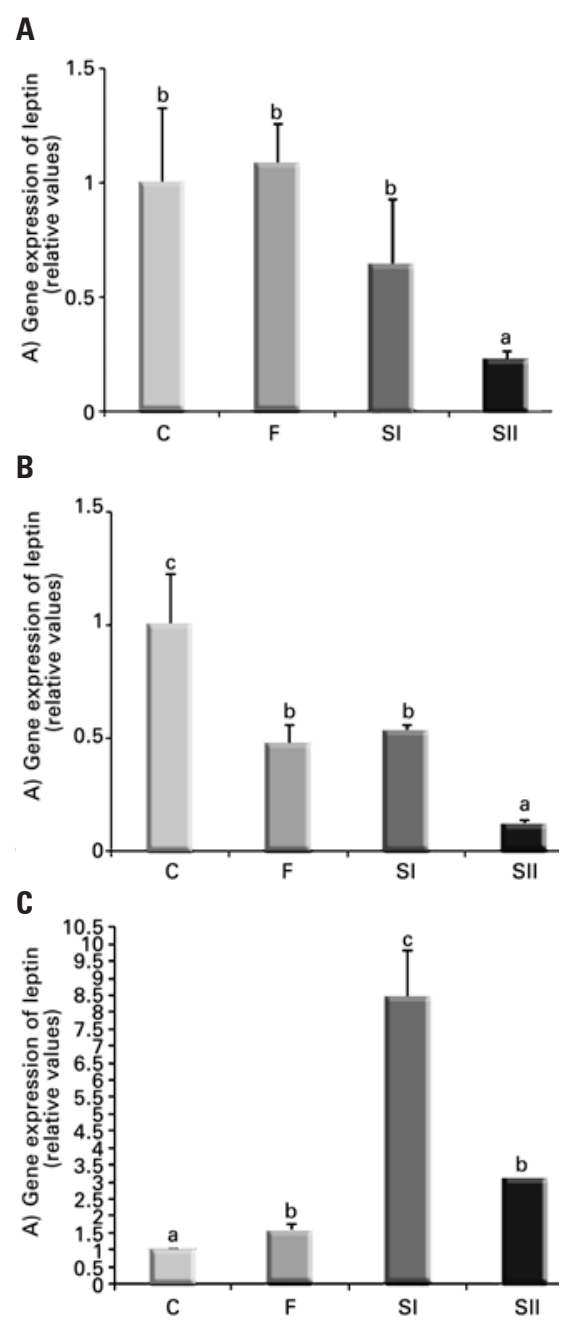

Figure 2. Effect of different doses of triiodothyronine on gene expression of leptin at 0.5 hour (A), 6 hours (B) and 24 hours (C). Data expressed as mean \pm standard deviation. We used analysis of variance, followed by Tukey's test. Same letters represent $p>0.05$; different letters represent $p<0.05$. Comparisons of Groups $\mathrm{F}$, SI or SIl versus $\mathrm{C}$, and $\mathrm{F}$ versus SI; F versus SII; SI versus SII. $\mathrm{n}=3$ for each treatment. C: Control; F: triiodothyronine at $10 \mathrm{nM}$; Sl: triiodothyronine at $100 \mathrm{nM}$; SII: triiodothyronine at $1,000 \mathrm{nM}$

Figure 2A shows the suppression of mRNA levels for leptin by $\mathrm{T} 3$ starting at 0.5 hour in SII compared with Groups C, F and SI. At 6 hours of incubation, there was a decrease in leptin mRNA in all treatment groups and this suppression was more pronounced in SII, compared with $\mathrm{F}$ and SI (Figure 2B). At 24 hours of incubation, leptin was increased in F, SI and SII compared with C, and the increase in SI was more pronounced than in $\mathrm{F}$ or SII (Figure 2C).

\section{T3 modulates mRNA levels for adiponectin starting at 0.5 hour at different doses}

Figure 3 shows the modulation of mRNA levels for adiponectin in 3T3-L1 adipocytes, in the absence (C) or presence (F, SI, SII, respectively) of T3 at different 
A

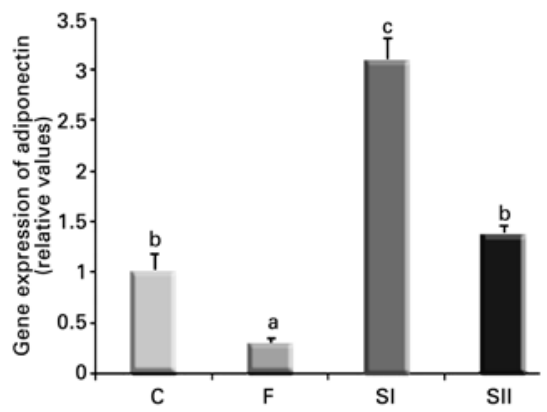

B

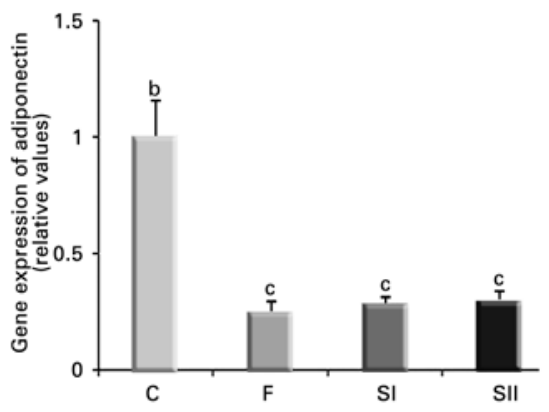

C

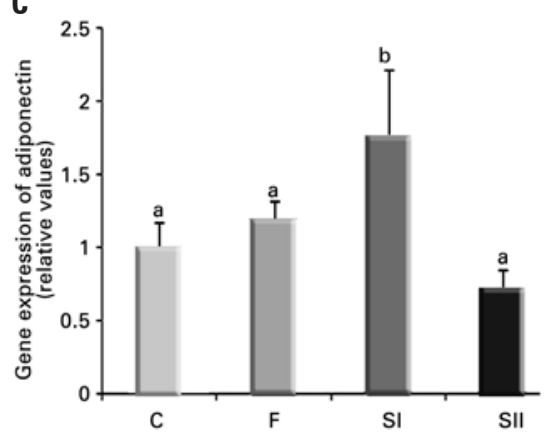

Figure 3. Effect of different doses of triiodothyronine on gene expression of adiponectin at 0.5 hour (A), 6 hours (B) and 24 hours (C). Data expressed as mean \pm standard deviation. We used analysis of variance, followed by Tukey's test. Same letters represent $p>0.05$; different letters represent $p<0.05$. Comparisons of Groups $\mathrm{F}$, SI or SIl versus $\mathrm{C}$, and $\mathrm{F}$ versus SI; F versus SII; SI versus SII. $\mathrm{n}=3$ for each treatment. C: Control; F: triiodothyronine at $10 \mathrm{nM}$; SI: triiodothyronine at $100 \mathrm{nM}$; SIl: triiodothyronine at $1,000 \mathrm{nM}$

timepoints $(0.5,6$ and 24 hours) by RT-PCR. At 0.5 hour, there was suppression of adiponectin expression in $\mathrm{F}$ and increase in SI when compared to $\mathrm{C}$ (Figure $3 \mathrm{~A})$. At 6 hours of incubation, the adiponectin gene expression was decreased by all doses (F, SI and SII) when compared with the control group (Figure 3B) At 24 hours, adiponectin returned to Group C levels in groups F and SII, and was increased in SI (Figure 3C).

\section{DISCUSSION}

Leptin and adiponectin differ from most other adipokines, because they are secreted exclusively by adipocytes. Although the details on all factors regulating their synthesis, secretion and clearance are not entirely known, plasma leptin levels increase in proportion to fat mass, while adiponectin levels decrease with weight gain. ${ }^{(36)}$ Leptin and adiponectin are involved in the regulation of energy balance, just like THs. ${ }^{(31)}$

We observed that adiponectin had higher expression than leptin in 3T3-L1 adipocytes, irrespective of the presence or absence of T3. This result can be explained by the fact that the 3T3-L1 adipocytes in this study did not represent a state of obesity. Obesity is based on an inflammatory process beginning with the increase of AT reserves, with hypertrophy and hyperplasia of this tissue, leading to the production of different proinflammatory molecules by both adipocytes themselves and the extracellular matrix that surrounds them. This, in turn, leads to the development of systemic low-grade inflammation. ${ }^{(37)}$ In obesity, leptin production is also increased ${ }^{(38,39)}$ while adiponectin expression is decreased, and consequently so are its antiinflammatory, anti-atherogenic and insulin-sensitivitypromoting properties. ${ }^{(40,41)}$

Some studies have found a negative correlation between THs and leptin ${ }^{(42,43)}$ while others have found an association. ${ }^{(44)}$ Wang et al. ${ }^{(45)}$ reported that although leptin and THs can act through the same pathways to regulate energy metabolism, the effects of leptin on metabolism do not depend on the presence of THs. However, leptin and THs may share some target sites and, therefore, have additive effects.

Our findings are in agreement with Yoshida et al., ${ }^{(24)}$ who observed modulation of leptin by T3 at 24 hours in 3T3-L1 adipocytes for all doses tested; however, our results showed that starting at 0.5 hour, T3 was already affecting the mRNA levels of this gene, which was suppressed by supraphysiological doses in SII. Previous studies by our group demonstrated an increase in leptin, both mRNA and protein, at 1 hour of incubation. ${ }^{(34)}$ Interestingly, at 6 hours of incubation, leptin is suppressed by the different doses of T3 administered to Groups F, SI and SII. This decrease is more pronounced for the $1,000 \mathrm{nM}$ dose, at which leptin expression decreases as the T3 concentration increases, just as observed in studies by Zabrocka et al. ${ }^{(43)}$ and Pinkney et al. ${ }^{(16)}$

In previous studies we demonstrated in rats subjected to food restriction that the physiological dose of T3 $(0.5 \mu \mathrm{g} / 100 \mathrm{~g})$ increased leptin expression, which translates into this being the dose required for proper expression of leptin in obese animals treated with caloric restriction. ${ }^{(46)}$ However, obese animals in a state of hyperthyroidism $(25 \mu \mathrm{g}$ T3 per $100 \mathrm{~g}$ weight) showed decreased leptin levels, as well as animals subjected to 
food restriction in the same hyperthyroid conditions. ${ }^{(47)}$ These results are in line with the findings of this study for the SII dose $(1,000 \mathrm{nM}$ T3) at 0.5 hour, and for the tested treatments at 6 hours.

As for adiponectin, some studies suggest that thyroid function may influence its serum levels. Some authors reported that the concentration of this adipokine was higher in hyperthyroidism, compared to euthyroid and hypothyroid conditions. ${ }^{(28,29)}$ This corroborates the results of our study, demonstrating that T3 affects the levels of adiponectin starting at 0.5 hour, with an increase in SI and decrease in $\mathrm{F}$.

Just like leptin at 6 hours, adiponectin was suppressed by all doses tested and, at 24 hours, levels returned to C values or exceeded normal values, such as in Group SI. Fasshauer et al., ${ }^{(48)}$ using the same experimental model, observed no change in adiponectin levels at 16 hours of incubation with the same dose administered to Group SII, which demonstrated that $\mathrm{T} 3$ effects fluctuate over time.

Our results corroborate those of Saito et al. ${ }^{(29)}$ and Yaturu et al. ${ }^{(28)}$ Adiponectin was found increased in the groups receiving supraphysiological doses of T3, mimicking hyperthyroidism. Cabanelas et al. ${ }^{(49)}$ concluded in their study that THs regulate mRNA expression of adiponectin in a tissue-specific fashion, without changing its secretion in the white AT.

Previous studies by our group showed that obese animals had decreased serum adiponectin and AT mRNA, and decreased leptin when compared with the control. Interestingly, the administration of supraphysiological T3 $(25 \mu \mathrm{g} / 100 \mathrm{~g})$ decreased body fat mass, serum levels of adiponectin and leptin, and mRNA. ${ }^{(50)}$ However, in contrast, an experimental study in rats with hyperthyroidism showed a significant increase in serum adiponectin. ${ }^{(51)}$ The findings of this in vitro study indicated that increase or decrease in leptin or adiponectin expression by T3 are dose- and time-dependent.

The results presented are important for understanding at which dose (physiological or supraphysiological) and over which period of time the modulation of adipokines leptin and adiponectin is triggered by $\mathrm{T} 3$ in mature adipocytes. It is now possible to aim for further studies focusing on the treatment of obesity with $\mathrm{TH}$ analogs, considering their ability to modulate the genes approached in this study.

\section{CONCLUSION}

Our results demonstrated rapid effects of triiodothyronine on the expression of leptin and adiponectin, starting at 0.5 hour at $1,000 \mathrm{nM}$ for leptin, and 100nM for adiponectin.
Triiodothyronine stimulated or inhibited the expression of adipokines in adipocytes at different timepoints and doses, which can be helpful to assist in the treatment of obesity, considering that in this condition, leptin is increased and adiponectin decreased.

\section{ACKNOWLEDGEMENTS}

This study had financial support from Fundação de Amparo à Pesquisa do Estado de São Paulo (FAPESP), [The State of São Paulo Research Foundation] under protocol number 2010/16911-4, for the development of the project. The Coordenação de Aperfeiçoamento de Pessoal de Nivel Superior (CAPES), [Coordination for the Improvement of Higher Education Personnel] granted scholarship for development of the project by the author. The funders did not take part in study design, data collection and analysis, decision to publish or manuscript preparation.

\section{REFERENCES}

1. Bernal J. Action of thyroid hormone in brain. J Endocrinol Invest. 2002;25(3): 268-88. Review.

2. Morreale de Escobar G, Obregon MJ, Escobar del Rey F. Role of thyroid hormone during early brain development. Eur J Endocrinol. 2004;151 Suppl 3:U25-U37. Review.

3. Viguerie N, Millet L, Avizou S, Vidal H, Larrouy D, Langin D. Regulation of human adipocyte gene expression by thyroid hormone. J Clin Endocrinol Metab. 2002;87(2):630-4.

4. Obregon MJ. Thyroid hormone and adipocyte differentiation. Thyroid. 2008; 18(2):185-95. Review.

5. Gregor MF, Hotamisligil GS. Inflammatory mechanisms in obesity. Annu Rev Immunol. 2011;29:415-45. Review.

6. Darimont C, Gaillard D, Ailhaud G, Negrel R. Terminal differentiation of mouse preadipocyte cells: adipogenic and antimitogenic role of triiodothyronine. Mol Cell Endocrinol. 1993;98(1):67-73.

7. Flier JS. Clinical review 94: What's in a name? In Search of leptin's physiologic role. J Clin Endocrinol Metab. 1998;83(5):1407-13. Review.

8. Fruebis J, Tsao TS, Javorschi S, Ebbets-Reed D, Erickson MR, Yen FT, et al. Proteolytic cleavage product of 30-kDa adipocyte complement-related protein increases fatty acid oxidation in muscle and causes weight loss in mice. Proc Natl Acad Sci USA. 2001;98(4):2005-10.

9. Tomas E, Tsao TS, Saha AK, Murrey HE, Zhang CC, Itani SI, et al. Enhanced muscle fat oxidation and glucose transport by ACRP30 globular domain: acetylCoA carboxylase inhibition and AMP-activated protein kinase activation. Proc Natl Acad Sci USA. 2002;99(25):16309-13.

10. Yamauchi T, Kamon J, Minokoshi Y, Ito Y, Waki H, Uchida S, et al. Adiponectin stimulates glucose utilization and fatty acid oxidation by activating AMPactivated protein Kinase. Nat Med. 2002;8(11):1288-95.

11. Oi Y, Takahashi N, Hileman SM, Patel HR, Berg AH, Pajvani UB, et al. Adiponectin acts in the brain to decrease body weight. Nat Med. 2004; 10(5):524-9. Erratum in: Nat Med. 2004;10(6):649.

12. Couillard C, Mauriège P, Imbeault P, Prud'homme D, Nadeau A, Tremblay A, et al. Hyperleptinemia is more closely associated with adipose cell hypertrophy than with adipose tissue hyperplasia. Int $\mathrm{J}$ Obes Relat Metab Disord. 2000;24(6):782-8. 
13. Hamilton BS, Paglia D, Kwan AY, Deitel M. Increased obese mRNA expression in omental fat cells from massively obese humans. Nat Med. 1995;1 (9):953-6.

14. Reinehr T, Isa A, de Sousa G, Dieffenbach R, Andler W. Thyroid hormones and their relation to weight status. Horm Res. 2008;70(1):51-7.

15. Kok P, Roelfsema F, Langendonk JG, Frölich M, Burggraaf J, Meinders AE, et al. High circulating thyrotropin levels in obese women are reduced after body weight loss induced by caloric restriction. J Clin Endocrinol Metab. 2005;90(8):4659-63.

16. Pinkney JH, Goodrick SJ, Katz J, Johnson AB, Lightman SL, Coppack SW, et al. Leptin and the pituitary-thyroid axis: a comparative study in lean, obese, ypothyroid and hyperthyroid subjects. Clin Endocrinol (0xf). 1998;49(5):583-8.

17. Chen MD, Song YM, Tsou CT, Lin WH, Sheu WH. Leptin concentration and the $\mathrm{Zn} / \mathrm{Cu}$ ratio in plasma in women with thyroid disorder. Biol Trace Elem Res. 2000;75(1-3):99-105.

18. Valcavi R, Zini M, Peino R, Casanueva FF, Dieguez $C$. Influence of thyroid status on serum immunoreactive leptin levels. J Clin Endocrinol Metab. 1997;82(5):1632-4.

19. Diekman MJ, Romijn JA, Endert E, Sauerwein H, Wiersinga WM. Thyroid hormones modulate serum leptin levels: observations in thyrotoxic and hypothyroid women. Thyroid. 1998;8(12):1081-6.

20. Sreenan S, Caro JF, Refetoff S. Thyroid dysfunction is not associated with alterations in serum leptin levels. Thyroid. 1997;7(3):407-9.

21. Matsubara M, Yoshizawa T, Morioka T, Katayose S. Serum leptin and lipids in patients with thyroid dysfunction. J Atheroscler Thromb. 2000;7(1):50-4.

22. Pinkney JH, Goodrick SJ, Katz JR, Johnson AB, Lightman SL, Coppack SW, et al. Thyroid and sympathetic influences on plasma leptin in hypothyroidism and hyperthyroidism. Int J Obes Relat Metab Disord. 2000;24 Suppl 2:S165-6.

23. Fain JN, Bahouth SW. Effect of tri-iodothyronine on leptin release and leptin mRNA accumulation in rat adipose tissue. Biochem J. 1998;332(Pt 2):361-6.

24. Yoshida T, Monkawa T, Hayashi M, Saruta T. Regulation of expression of leptin mRNA and secretion of leptin by thyroid hormone in 3T3-L1 adipocytes. Biochem Biophys Res Commun. 1997;232(3):822-6.

25. Simó R, Hernández C, Zafon C, Galofré P, Castellanos JM, Mesa J. Short-term hypothyroidism has no effect on serum leptin concentrations. Diabetes Obes Metab. 2000;2(5):317-21.

26. Obermayer-Pietsch BM, Frühauf GE, Lipp RW, Sendlhofer G, Pieber TR. Dissociation of leptin and body weight in hyperthyroid patients after radioiodine treatment. Int J Obes Relat Metab Disord. 2001;25(1):115-20.

27. Ahima RS, Flier JS. Adipose tissue as an endocrine organ. Trends Endocrinol Metab. 2000;11(8):327-32. Review.

28. Yaturu S, Prado S, Grimes SR. Changes in adipocyte hormones leptin, resistin, and adiponectin in thyroid dysfunction. J Cell Biochem. 2004;93(3):491-6.

29. Saito $T$, Kawano T, Saito T, Ikoma A, Namai K, Tamemoto $H$, et al. Elevation of serum adiponectin levels in Basedow disease. Metabolism. 2005;54(11):1461-6.

30. Iglesias P, Alvarez Fidalgo P, Codoceo R, Díez JJ. Serum concentrations of adipocytokines in patients with hyperthyroidism and hypothyroidism before and after control of thyroid function. Clin Endocrinol (0xf). 2003;59(5):621-9.

31. Vendrell J, Broch M, Vilarrasa N, Molina A, Goméz JM, Gutiérrez C, et al. Resistin, adiponectin, ghrelin, leptin, and proinflammatory cytokines: relationships in obesity. Obes Res. 2004;12(6):962-71.

32. Moore R, Grant AM, Howard AN, Mills IH. Treatment of obesity with triiodothyronine and a very-low-calorie liquid formula diet. Lancet. 1980; 1(8162):223-6.

33. Moreira-Andrés MN, Del Cañizo-Gómez FJ, Black EG, Hoffenberg R. Longterm evaluation of thyroidal response to partial calorie restriction in obesity. Clin Endocrinol (Oxf). 1981;15(6):621-6.
34. de Oliveira M, Luvizotto Rde A, Olimpio RM, De Sibio MT, Conde SJ, Biz Rodrigues Silva $\mathrm{C}$, et al. Triiodothyronine increases mRNA and protein leptin levels in short time in 3T3-L1 adipocytes by PI3K pathway activation. PLoS One. 2013;18;8(9):e74856.

35. Livak KJ, Schmittgen TD. Analysis of relative gene expression data using real-time quantitative PCR and the 2(-Delta Delta C(T))Method. Methods. 2001;25(4):402-8.

36. Gray SL, Vidal-Puig AJ. Adipose tissue expandability inthe maintenance of metabolic homeostasis. Nutr Rev. 2007;65(6 Pt 2):S7-12.

37. Hansen D, Dendale P, Beelen M, Jonkers RA, Mullens A, Corluy L, et al Plasma adipokine and inflammatory marker concentrations are altered in obese, as opposed to non-obese, type 2 diabetes patients. Eur J Appl Physiol. 2010;109(3):397-404.

38. Ahima RS. Adipose tissue as an endocrine organ. Obesity (Silver Spring). 2006;14 Suppl 5:242S-249S. Review.

39. Fain J. Release of inflammatory mediators by human adipose tissue is enhanced in obesity and primarily by the nonfat cells: a review. Mediators Inflamm. 2010;2010:513948. Review.

40. Engeli S, Feldpausch M, Gorzelniak K, Hartwig F, Heintze U, Janke J, et al. Association between adiponectin and mediators of inflammation in obese women. Diabetes. 2003;52(4):942-7.

41. Simpson KA, Singh MA. Effects of exercise on adiponectin: a systemic review. Obesity (Silver Spring). 2008;16(2):241-56. Review.

42. Escobar-Morreale HF, Escobar del Rey F, Morreale de Escobar G. Thyroid hormones influence serum leptin concentrations in the rat. Endocrinology. 1997;138(10):4485-8.

43. Zabrocka L, Klimek J, Swierczynski J. Evidence that triiodothyronine decreases rat serum leptin concentration by down-regulation of leptin gene expression in white adipose tissue. Life Sci. 2006;79(11):1114-20.

44. Näslund E, Andersson I, Degerblad M, Kogner P, Kral JG, Rössner S, et al. Associations of leptin, insulin resistance and thyroid function with long-term weight loss in dieting obese men. J Intern Med. 2000;248(4):299-308.

45. Wang JL, Chinookoswong N, Yin S, Shi ZO. Calorigenic actions of leptin are additive to, but not dependent on, those of thyroid hormones. Am J Physiol Endocrinol Metab. 2000;279(6):E1278-85.

46. Luvizotto RA, Conde SJ, Síbio MT, Nascimento AF, Lima-Leopoldo $A P_{\text {, }}$ Leopoldo AS, et al. Administration of physiologic levels of triiodothyronine increases leptin expression in calorie-restricted obese rats, but does not influence weight loss. Metabolism. 2010;59(1):1-6.

47. Luvizotto RA, Síbio MT, Olímpio RM, Nascimento AF, Lima-Leopoldo AP, Leopoldo A, et al. Supraphysiological triiodothyronine doses diminish leptin and adiponectin gene expression, but do not alter resistin expression in calorie restricted obese rats. Horm Metab Res. 2011;43(7):452-7.

48. Fasshauer M, Klein J, Neumann S, Eszlinger M, Paschke R. Hormonal regulation of adiponectin gene expression in 3T3-L1 adipocytes. Biochem Biophys Res Comm. 2002;290(3):1084-9.

49. Cabanelas A, Cordeiro A, Santos Almeida NA, Monteiro de Paula GS, Coelho VM, Ortiga-Carvalho TM, et al. Effect of triiodothyronine on adiponectin expression and leptin release by white adipose tissue of normal rats. Horm Metab Res. 2010;42(4):254-60.

50. Luvizotto Rde A, do Nascimento AF, Síbio MT, Olímpio RM, Conde SJ, LimaLeopoldo AP, et al. Experimental hyperthyroidism decreases gene expression and serum levels of adipokines in obesity. Scientific World Journal. 2012; 2012:780890.

51. Aragão CN, Souza LL, Cabanelas A, Oliveira KJ, Pazos-Moura CC. Effect of experimental hypo- and hyperthyroidism on serum adiponectin. Metabolism. 2007;56(1):6-11. 